\title{
Nursing Student's Experience on Locus of Control and Its Relation with Learning Performance and Academic Support: A Comparative Study
}

\author{
Wafaa Abd El-Azeem El-Hosany ${ }^{1}$, Wafaa Fathi Sleem ${ }^{2}$ \\ ${ }^{1}$ Department of Nursing Administration, Faculty of Nursing, Suez Canal University, Ismailia, Egypt \\ ${ }^{2}$ Department of Nursing Administration, Faculty of Nursing, Mansoura University, Mansoura, Egypt
}

Email address:

dr_wafaasleem@yahoo.com (W. F. Sleem)

\section{To cite this article:}

Wafaa Abd El-Azeem El-Hosany, Wafaa Fathi Sleem. Nursing Student's Experience on Locus of Control and Its Relation with Learning Performance and Academic Support: A Comparative Study. American Journal of Nursing Science. Vol. 6, No. 4, 2017 , pp. 315-323. doi: 10.11648/j.ajns.20170604.16

Received: April 15, 2017; Accepted: May 11, 2017; Published: July 12, 2017

\begin{abstract}
Nowadays researchers are paying more attention to factors that may lead to the promotion or inhibition of the academic performance and socializing the education through fostering the academic support. Cognitive abilities are no longer sufficient to determine academic success or failure, it is important to investigate the psychological skills as locus of control. The study aimed to investigate nursing student's experience on locus of control and its relation with learning performance and academic support. Cross section analytical study design was used to fulfill this study. This study was conducted at two settings: Faculty of Nursing, Mansoura University and Faculty of Nursing, Suez Canal University. The study sample includes 222 students from Mansoura University and 186 students from Suez Canal University. Data of the present study were collected by using three tools namely: Internal-External Locus of Control Scale, Learning Performance Scale and perceived academic support scale. Results of the present study indicated that more than half of students had internal locus of control rather than external locus of control, 55.9\% of students had internal locus of control in Suez Canal University and 59.5\% in Mansoura University, high learning performance and high perceived academic support of the participated students. There was no significant correlation between locus of control (internal or external) and learning performance or perceived academic support. more than half of students had internal locus of control rather than external locus of control and there was no significant correlation between locus of control (internal or external) and learning performance or perceived academic support. According to study findings academic administrators should pay attention to help students to improve and understand how their self perceptions may affect their academic performance.
\end{abstract}

Keywords: Internal-External Locus of Control, Learning Performance, Perceived Academic Support

\section{Introduction}

In the era of rapidly growing changes, an organization must adapt those changes to achieve success as well as think about student life and their best future. They must think about the student's activities regarding their studies likewise their concentration in studies and their best performance in which subjects. To achieve such aspiration university teaching and learning must take into account students' personality characteristics as locus of control [1].

The concept 'locus of control' derives from social learning theory. Rotter [2] defined locus of control as the degree of control that individuals believe they have over the outcome of certain situations, sited in his 1966 monograph, Locus of control is a personality trait that focus on cognitive abilities that anticipate expected outcomes of events in a person's life [3].When reinforcement is perceived by the subject as following some action, the result may be due to luck, chance, fate, or unpredictable due to complexities of the forces surrounding him [4].

Locus of control defined as a personality trait of how individuals perceive their ability to control life events or environment. It determines the particular behavior and the outcomes of practicing these behaviors, characterized by one 
continuum on which two extremes can be recognized: internal locus of control and external locus of control [5].The individuals with internal locus of control believe that they have a big role on affecting and direct the events in their lives whatever way they desire, they assess themselves as having the power for the attitude they want to display, they having high positive ego concept. The individuals who have external locus of control correlate the events affecting their lives to perceptions such as chance, fate or unpredictable which are out of their control [6].

Many of people resist change, individuals who are selfcontrolled and have internal locus of control can adapt to the change and uncertainty more easily, individual can make self-control and dominant of his fate, give positive reactions to the change. Individuals according to locus of control are classified in two groups, internals and externals. People with internal locus of control have a strong belief in themselves and their abilities; they can monitor the events or behaviors with their own fate in their life. They believe that the responses that they take from environment are the result of their attitudes. While, people with external locus of control, correlate the events and reactions in their life, whether success or failures to the external attributes not related to them, they back success to an easy exam, while failure to environmental factors [7]. Internal locus of control, strong personal control and influenced by inside forces while external locus of control, weak personal control and influenced by outside forces [8].

Literatures focus on locus of control as vital concepts in the context of learning difficulty and attitude change. Locus of control can help students to analyze the events in their lives as the result of their attitudes and their own decisions, so they can shape their future. On the other hand the reactions in their life may be due to chance, fate or outside forces. Rotter [2] studied Social Learning Theory, confirmed that some students who have gained success, prizes or reinforcements as a result of their efforts and abilities while some students display these events as unpredictable or out of their control [9]. Nowadays researchers are paying more attention to factors that may lead to the promotion or inhibition of the academic performance. Chamorro-Premuzic and Furnham [10] stated that individual differences in academic success or failure are no longer depending on cognitive abilities alone. It was observed that the various students choose different ways to receive and process the information that are served by their teachers, or students who attribute their performances of learning to the faith, fate or random coincidence, while others believe that their behavior is governed by their thoughts and personal efforts. Rotter [2] hypothesized upon a relationship between locus of control and school results. He theorized that people with internal locus have greater performance than those who feel they have less control over the situation [11]. Perceived academic support traditionally defined as peer leadership, for the purpose of one to one studying or preparation for exams [12]. Peer leadership support is very important for the students especially in academic skill development, professional development, development of personal efficacy feeling as well as skill development for communication and establishing bilateral relationship. Maxvell [13] defines academic support as "socializing the education". Academic support includes the assistance interaction of students and teachers academically, includes the solution of academic problems faced by students and academic encouragement, academic support has a positive effect on student with difficulty to learn and low academic performance [3]. Lack of academic support for the students causes the students to look for it from other students [14].

Significance of the study:

Organizational learning is essential factor in increasing students' performance, so it is necessary for organizations to fulfill learning function in an arrangement and shape their knowledge and experiences gained by different means as students differences in academic success or failure are no longer depending on cognitive abilities alone. So, it is important to investigate the contributions of psychological skills such as self- locus of control to the prediction of academic performance, whether students have internal or external locus of control; furthermore, which locus of control they possess in the learning period [15]. Also there is no significant literature about the relationship between these psychological traits and academic support.

\section{Subjects and Methods}

\subsection{Research Aim and Questions}

This study was aiming to investigate nursing student's experience on locus of control and its relation with learning performance and academic support at Faculty of Nursing, Mansoura University and Faculty of Nursing, Suez Canal University. The following research questions guide the research study:

1: Is there any relationship between Internal-External Locus of Control and other study variables?

2: What are the difference changes between locus of control, learning performance and academic support at faculty of nursing, Mansoura University and Suez Canal University?

\subsection{Research Design}

Cross section analytical study design was used to fulfill this study.

\subsection{Setting}

The study was carried out in two settings: Faculty of Nursing, Mansoura University and Faculty of Nursing, Suez Canal University.

\subsection{Sample}

The study sample integrated all available nursing students educated in the academic year 2015-2016 and who are accessible at the time of data collection in the previously 
mentioned two setting and who accept to participate in the study. Their total number was 222 students from Faculty of Nursing, Mansoura University and 186 students from Faculty of Nursing, Suez Canal University.

\subsection{Tools of Data Collection}

Tool 1. Internal-External Locus of Control Scale, developed by Rotter [2] to assess nursing student's experience on Locus of Control includes two parts.

Part 1: Internal locus of control. Part 2: External locus of control.

Both parts had (14) items cover (7) dimensions as: abilities, responsibilities, change, environment, stress, job satisfaction and work motivation.

Responses ranged from 1 to 5 (1= strongly disagree, $2=$ somewhat disagree, $3=$ neither agree nor disagree, $4=$ somewhat agree, and $5=$ strongly agree).

A higher score $=$ External Locus of Control A lower score $=$ Internal Locus of Control (Rotter, 1966).

Tool 2. Learning Performance Scale developed by Gungor [16] to assess nursing student's experience on their Learning Performance. It includes 25 items under seven dimensions, which are activity, perception, listening, abilities, imitation, reading and noticing.

Responses were measured on five point Likert scale that ranged from 1 to $5(1=$ strongly disagree, $2=$ somewhat disagree, $3=$ neither agree nor disagree, $4=$ somewhat agree, and $5=$ strongly agree).

The researcher classified scores in to three levels based on cut of point $60 \%$

Tool 3. perceived academic support scale developed by researchers based on related reviews [12], [13], [3] to assess students' perception of the support received in their nursing program. It is categorized into: Psychological support (12items) and functional support (12 items).

Response to items was measured in four point likert scale ranging from 1-4 from strongly disagree to strongly agree. Higher scores indicating higher perceived academic support.

\subsection{Validation and Reliability of the Tools}

The data collection tools were reviewed by five professors in nursing administration. They were asked to examine the questionnaire for content coverage, clarity, wording, length, format, and overall appearance. Based on experts' comment and recommendations minor changes had been made for face and content validation. Cronbach alpha coefficient was used to assess the internal consistency of the tools. InternalExternal Locus of Control Scale, alpha Cronbach $=.931$, Learning Performance Scale, alpha Cronbach $=.943$ and Academic support scale, alpha Cronbach $=.83$.

\subsection{Pilot Study}

A pilot study conducted before performing the main study. The questionnaires tested on a sample of 40 students, excluded from the main study sample. The aim was to check the clarity, completeness and practicability of the survey tools, and time needed to fulfill the questionnaires.

\subsection{Field Work}

Data collection was started from March 2016 to June 2016. Regarding the self-administrated questionnaires were filled by the students through 15-20 minutes.

\subsection{Administrative and Ethical Considerations}

A faculties' dean permission was obtained to conduct the study. Ethical approval was obtained from the research ethics committee from the two setting. Privacy and confidentiality during data collection were assured. Participation in research is voluntary.

\subsection{Statistical Analysis}

Data were analyzed using Statistical Package for Social Sciences (SPSS) version 21 analyzing and scoring sheets of the HSPSC survey were followed in tabulation and calculation. Number and percentage distribution were used to determine the highest responses. The confidence level chosen for the study was $95 \%$. The differences were considered significant if the $\mathrm{p}$ - value was less than 0.05 at the appropriate degrees of freedom. Pearson correlation analysis was used for assessment of interrelationship among quantitative variables and score.

\section{Results}

Table 1. clarified that, $54.4 \%$ of the participated students were from El Mansoura University. Also this table shows that, mean $\pm \mathrm{SD}$ of age were $21.9 \pm 0.9$.

Figure 1. shows that, more than half $(55 \%)$ of the participated students were at the 4 academic years.

Figure 2. illustrated that, $13.2 \%$ of the participated students strongly agreed and $28 \%$ of them agreed regarding internal locus of control, while only $8 \%$ strongly agreed and $24.7 \%$ of them agreed regarding external locus of control.

Table 2. shows that, the item of while I am studying, I often stop and do something else in dimension of activity the most item affect learning performance with percentage of $73.3 \%$ as perceived by the participated students, then the items of I can understand better when I see things; I learn by doing and practicing; I like the activities which I participate actively in dimension of perception and understanding as follow; $69.6 \%, 69.2 \%, 68.1 \%$ respectively and the item of I like my teacher to correct my mistakes by explaining them to me in the dimension of method with percentage of $67.6 \%$, while the least item affect learning performance the item I talk too much in class in dimension of concentration with percentage of $38 \%$ as perceived by the participated students.

Figure 3. illustrated that, the Perceived academic support by the participated students were high more than $70 \%, 26.1 \%$ of the participated students were strongly agreed regarding Perceived academic support total score and $45.6 \%$ of them were agreed regarding Perceived academic support total score.

Table 3. shows that, there was significant relationship 
between internal locus of control and dimension of perception and understanding $(\mathrm{r}=0.17 \& \mathrm{p}=0.001)$, dimension of noticing $(r=-0,11 \& p=0.025)$ respectively. While there was significant relationship between external locus of control and learning performance total $\operatorname{score}(\mathrm{r}=-.013 \& \mathrm{p}=0.010)$, also there was significant relationship between external locus of control and the dimension of perception and understanding $(r=-0.11 \& p=0.028)$, dimension of abilities $(r=-0.14 \&$ $\mathrm{p}=0.005)$ respectively.

Table 4. shows that, the mean scores of learning performance, perceived academic support, internal-external locus of control were higher in Mansoura compering to Suez Canal University. Also this table reveals that all dimensions of learning performance higher in Mansoura than Suez Canal University except the dimension of perception and understanding in Suez Canal University Mean 19.0 and in Mansoura Mean 18.4.

Figure 4. shows that, all study variables were high in Suez Canal University expect internal-external locus of control total score low $=57.5 \%$ and external locus of control low $=67.2 \%$.

Figure 5. shows that, all study variables were high in Mansoura University and the highest score was the perceived academic support high $=88.3 \%$.

Table 1. Percentage distribution of the participated students regarding their socio demographic characteristics $(n=408)$.

\begin{tabular}{lll}
\hline Socio-demographic characteristics & n & \% \\
\hline -University & & \\
\hline Suez Canal University & 186 & 45.6 \\
Mansoura University & 222 & 54.4 \\
Age mean \pm SD & $21.9 \pm 0.9$ & \\
\hline
\end{tabular}

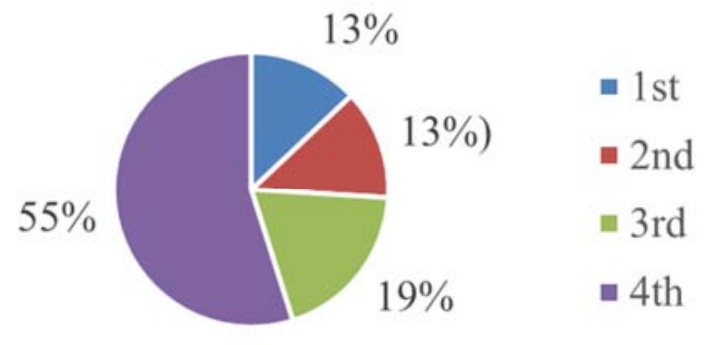

Figure 1. Percentage distribution of the participated students among the 4 academic years $(n=408)$.

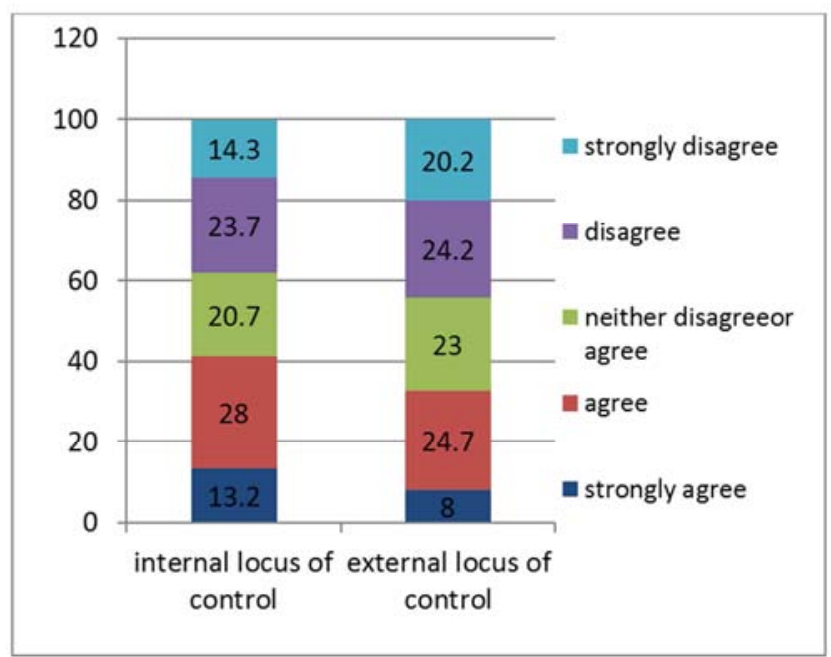

Figure 2. Percentage distribution of locus of control by the participated students $(n=408)$.

Table 2. Percentage distribution of the participated students regarding dimensions of learning performance $(n=408)$.

\begin{tabular}{|c|c|c|c|}
\hline Learning performance dimensions & High & Moderate & Low \\
\hline \multicolumn{4}{|l|}{ Activity. } \\
\hline 1. While I am studying, I often stop and do something else & $199(73.3 \%)$ & $55(13.5 \%)$ & $54(13.2 \%)$ \\
\hline 2. I like sport activities at faculty and attend them. & $229(56.2 \%)$ & $78(19.1 \%)$ & $101(24.7 \%)$ \\
\hline 3. I do what can for every event that can act and take part in them in class. & $214(52.5 \%)$ & $129(31.6 \%)$ & $65(15.9 \%)$ \\
\hline 4. Teachers think that move a lot in the classroom. & $191(46.9 \%)$ & $113(27.7 \%)$ & $104(25.4 \%)$ \\
\hline 5. I talk too much in class. & $155(38 \%)$ & $89(21.8 \%)$ & $164(40.2 \%)$ \\
\hline \multicolumn{4}{|l|}{ Perception and Understanding } \\
\hline I hold every new thing in my hands and observe them. & $248(60.8 \%)$ & $88(21.6 \%)$ & $72(17.7 \%)$ \\
\hline I learn by doing and practicing. & $282(69.2 \%)$ & $80(19.6 \%)$ & $46(11.2 \%)$ \\
\hline I can understand better when I see things. & $284(69.6 \%)$ & $69(16.9 \%)$ & $55(13.5 \%)$ \\
\hline I like the activities which I participate actively. & $278(68.1 \%)$ & $76(18.6 \%)$ & $54(13.2 \%)$ \\
\hline I quickly perceive things showed in maps, posters and diagrams & $245(60.1 \%)$ & $83(20.3 \%)$ & $80(19.6 \%)$ \\
\hline \multicolumn{4}{|l|}{ Listening } \\
\hline I like listening to book cassettes. & $207(50.7 \%)$ & $116(28.4 \%)$ & $85(20.8 \%)$ \\
\hline I like faculty songs very much and learn them quickly. & $215(52.7 \%)$ & $88(21.6 \%)$ & $105(25.7 \%)$ \\
\hline I Like reading aloud. & $231(56.6 \%)$ & $91(22.3 \%)$ & $86(21.1 \%)$ \\
\hline \multicolumn{4}{|l|}{ Abilities } \\
\hline I like making practical jokes to my friends. & $259(63.5 \%)$ & $88(21.6 \%)$ & $61(14.9 \%)$ \\
\hline I like music and rhythm to learn better. & $228(58.3 \%)$ & $91(22.3 \%)$ & $89(21.8 \%)$ \\
\hline I like doing things by using my hands. & $267(65.5 \%)$ & $80(19.6 \%)$ & $61(14.9 \%)$ \\
\hline \multicolumn{4}{|l|}{ Method } \\
\hline I prefer telling to writing. & $228(55 \%)$ & $93(22.3 \%)$ & $87(21.3 \%)$ \\
\hline I like my teacher to correct my mistakes by explaining them to me. & $276(67.6 \%)$ & $78(19.1 \%)$ & $54(13.2 \%)$ \\
\hline I'd rather listen to the teacher than study by myself. & $249(61 \%)$ & $98(24.0 \%)$ & $61(15 \%)$ \\
\hline $\begin{array}{l}\text { I understand a subject better if somebody tells or reads it, rather than reading it on } \\
\text { my own. }\end{array}$ & $223(54.7 \%)$ & $98(24.0 \%)$ & $87(21.3 \%)$ \\
\hline Reading & & & \\
\hline
\end{tabular}




\begin{tabular}{|c|c|c|c|}
\hline Learning performance dimensions & High & Moderate & Low \\
\hline I like reading novels. & $240(58.8 \%)$ & $87(21.3 \%)$ & $81(19.9 \%)$ \\
\hline I like to read silently. & $234(57.3 \%)$ & $83(20.3 \%)$ & $91(22.3 \%)$ \\
\hline \multicolumn{4}{|l|}{ Noticing } \\
\hline I always want to clean the board, opening/closing the windows or the door. & $191(46.8 \%)$ & $101(24.8 \%)$ & $116(28.4 \%)$ \\
\hline My teachers and parents often tell me not to touch the objects. & $202(47 \%)$ & $93(22.8 \%)$ & $131(27.6 \%)$ \\
\hline I understand better if events and subjects are dramatized & $254(62.3 \%)$ & $88(21.6 \%)$ & $66(16.2 \%)$ \\
\hline
\end{tabular}

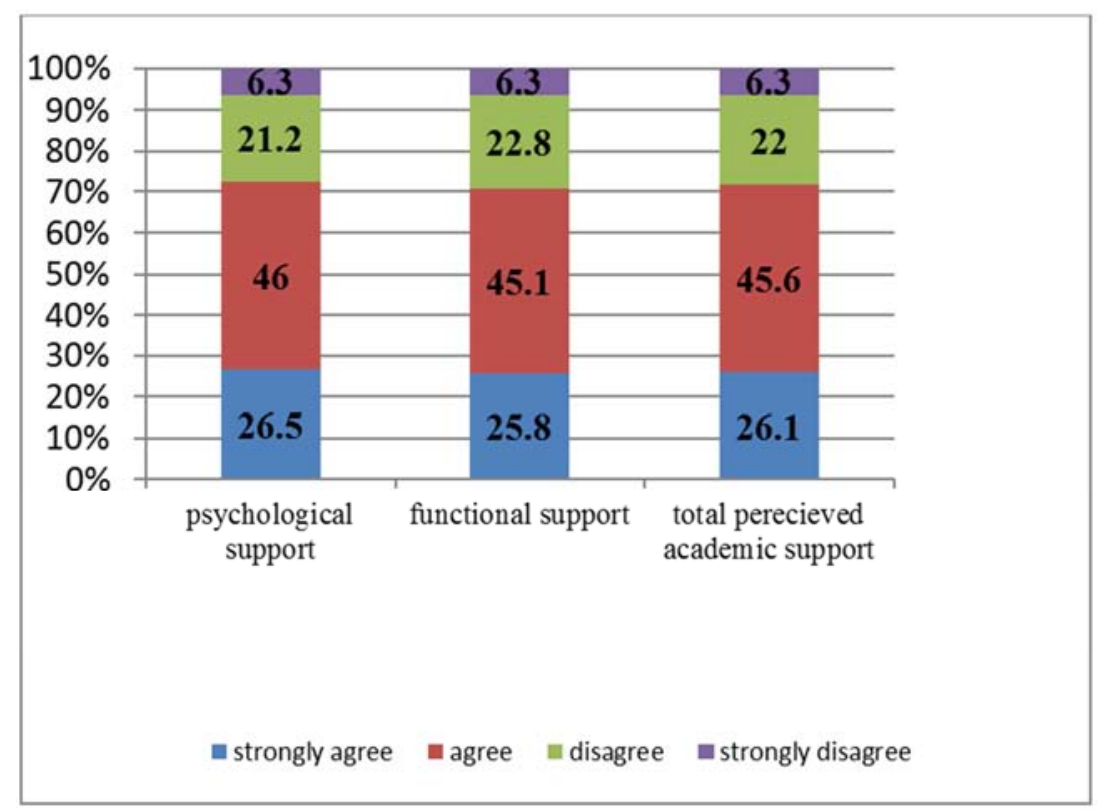

Figure 3. Percentage distribution of Perceived academic support by the participated students $(n=408)$.

Table 3. Correlation Coefficient r between Internal-External Locus of Control and other study variables.

\begin{tabular}{|c|c|c|c|c|}
\hline \multirow{2}{*}{ Study variables } & \multicolumn{2}{|c|}{ Internal Locus of Control } & \multicolumn{2}{|c|}{ External Locus of Control } \\
\hline & $\mathbf{r}$ & P value & $\mathbf{r}$ & P value \\
\hline Learning performance dimensions: & -0.00 & 0.984 & $-0.13^{*}$ & 0.010 \\
\hline -Activity & -0.04 & 0.467 & -0.05 & 0.295 \\
\hline - Perception and Understanding & $0.17^{*}$ & 0.001 & $-0.11^{*}$ & 0.028 \\
\hline - Listening & -0.06 & 0.206 & -0.06 & 0.218 \\
\hline - Abilities & -0.01 & 0.893 & $-0.14^{*}$ & 0.005 \\
\hline - Method & 0.04 & 0.467 & -0.07 & 0.184 \\
\hline - Reading & -0.00 & 0.959 & -0.07 & 0.181 \\
\hline - Noticing & $-.011^{*}$ & 0.025 & -0.06 & 0.260 \\
\hline Perceived academic support: & 0.04 & 0.474 & -0.07 & 0.191 \\
\hline -Functional support & 0.01 & 0.840 & -0.08 & 0.115 \\
\hline -Psychological support & 0.05 & 0.317 & -0.04 & 0.473 \\
\hline
\end{tabular}

Table 4. Comparison between Suez Canal and Mansoura Universities as regard to mean and standard deviation of different variables.

\begin{tabular}{|c|c|c|c|}
\hline \multirow{2}{*}{ Study Variables } & \multicolumn{2}{|l|}{ Mean \pm SD } & \multirow{2}{*}{ P value } \\
\hline & Suez Canal & Mansoura & \\
\hline Learning performance dimensions: & $86.9 \pm 18.4$ & $90.1 \pm 14.6$ & $0.048 *$ \\
\hline -Activity. & $16.2 \pm 4.2$ & $17.6 \pm 3.9$ & $0.001 *$ \\
\hline - Perception and Understanding & $19.0 \pm 4.6$ & $18.4 \pm 3.7$ & 0.158 \\
\hline -Listening & $9.7 \pm 3.0$ & $10.9 \pm 2.5$ & $<0.001 *$ \\
\hline -Abilities & $11.0 \pm 3.2$ & $10.8 \pm 2.7$ & 0.483 \\
\hline -Method & $14.3 \pm 3.8$ & $14.6 \pm 3.4$ & 0.496 \\
\hline -Reading & $7.1 \pm 2.3$ & $7.2 \pm 1.9$ & 0.579 \\
\hline -Noticing & $9.6 \pm 2.9$ & $10.7 \pm 2.8$ & $<0.001^{*}$ \\
\hline Perceived academic support: & $69.5 \pm 13.7$ & $70.3 \pm 11.9$ & 0.524 \\
\hline -Psychological & $34.7 \pm 7.4$ & $35.5 \pm 6.5$ & 0.254 \\
\hline -Function & $34.8 \pm 7.4$ & $34.9 \pm 6.4$ & 0.923 \\
\hline Internal-External Locus of Control: & $37.5 \pm 11.4$ & $42.9 \pm 10.7$ & $<0.001^{*}$ \\
\hline -Internal Locus of Control & $20.9 \pm 7.2$ & $21.3 \pm 6.3$ & 0.511 \\
\hline -External Locus of Control & $16.6 \pm 6.8$ & $21.6 \pm 5.7$ & $<0.001^{*}$ \\
\hline
\end{tabular}




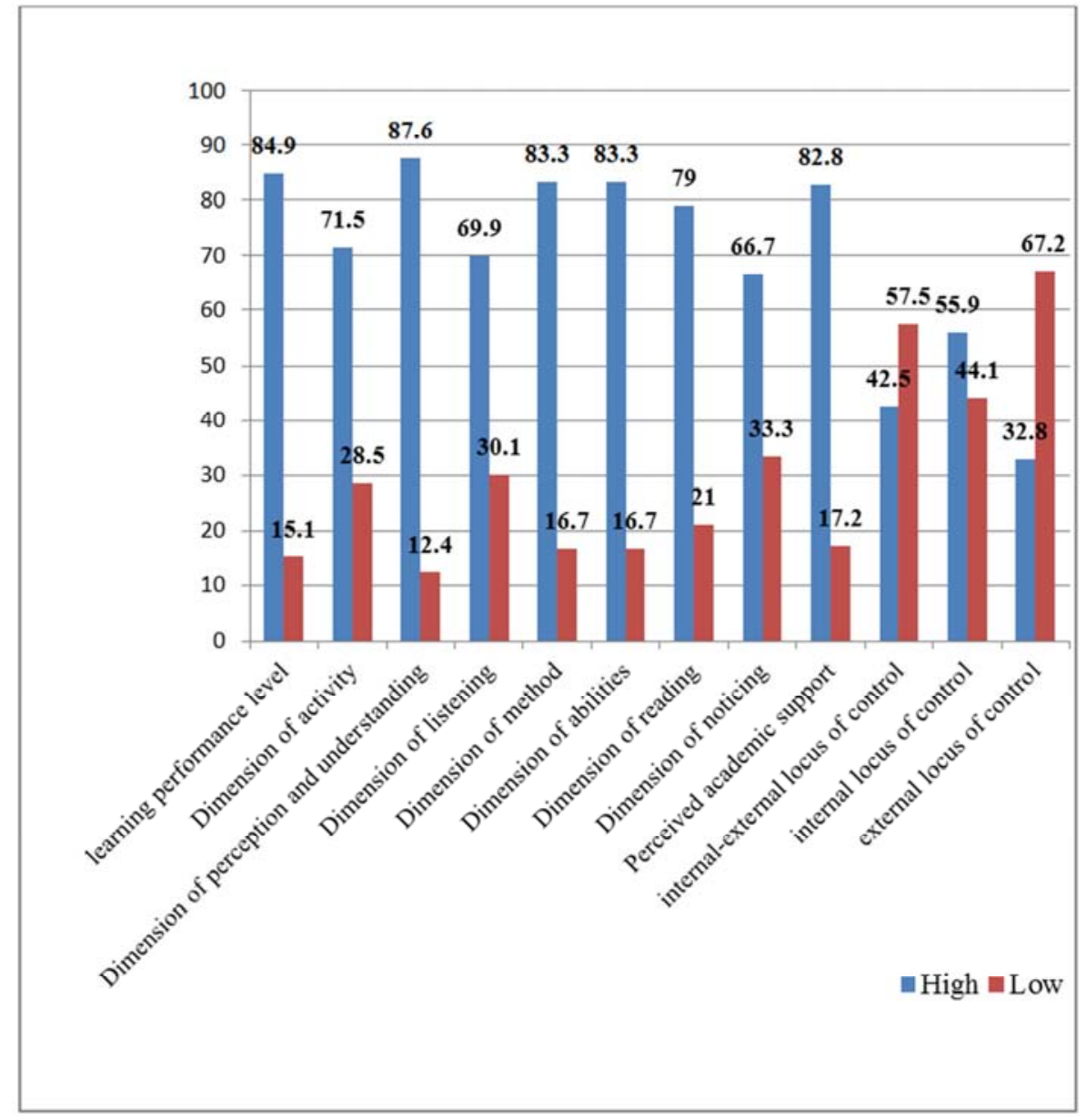

Figure 4. Percentage distribution regarding levels of learning performance, academic support and Internal-External locus of control in Suez Canal University $(n=186)$.

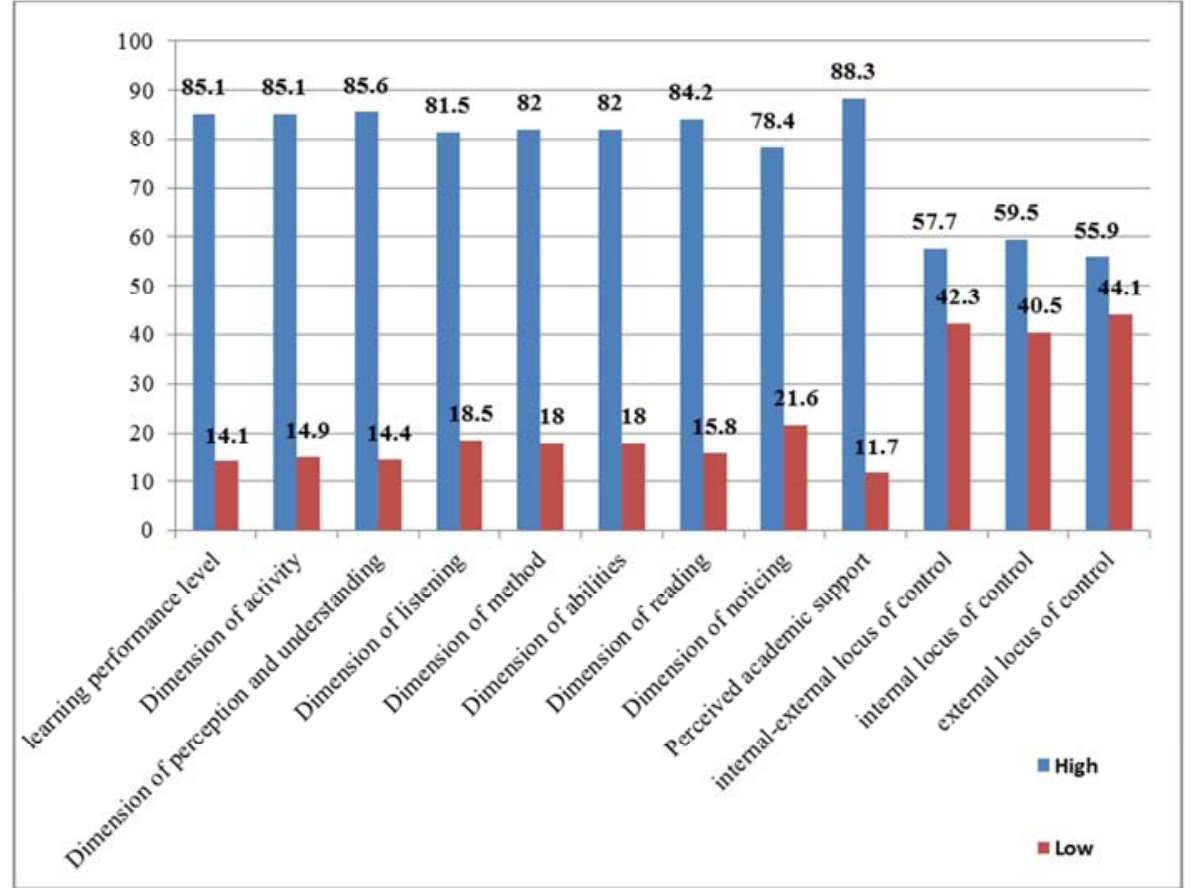

Figure 5. Percentage distribution regarding levels of learning performance, academic support and Internal-External locus of control in Mansoura University $(n=222)$. 


\section{Discussion}

Academic performance is one of the top priorities in education. It is so important that parents, teachers and society in general worried and apprehensive about the ways to improve it, as educational outcomes is paramount to the economic, scientific and technological advancement of a nation. It is important to investigate the contributions of psychological skills not only the IQ achievement such as self- locus of control to the prediction of academic performance, whether students have internal or external locus of control as the individuals, who have the internal locus of control, think that they have a big role on affecting the events which influence their lives. Furthermore, they assess themselves as possessing the power for the attitude they want to display by having the positive ego concept, and they believe that they can direct their lives whatever way they desire [17].

As regard to age of the participated students, the result of the current study revealed that, more than half of the participated students were at the $4^{\text {th }}$ academic year. This result was aligned with [18] who carried out a study entitled "The Effects of Locus of Control on Learning Performance: A Case of an Academic Organization" they reported that the majority of the participated students aged between 20 and 30 years.

Concerning to nursing student's experience regarding locus of control, the present study revealed that, the participated students with internal locus of control have got a higher ratio than the ones with external locus of control. This result could be interpreted as internal locus of control increases with age and in the present study more than half of the participated students were in the fourth academic year, in other words they become more self-control about their decisions and their expected outcomes depend on their own attitudes rather than students in first and second academic year.

This result was supported by previous studies; Abid et al. [1] studied The Effect of Locus of Control on Academic Performance of The Students at Tertiary Level in Pakistan, [18]. While this result in contrast with [19] who carried out a study in USA entitled "The Impact of Locus of Control Reinforcement and Metacognition on Mathematics Achievement of Undergraduate Students" he reported that external locus of control was higher than internal locus of control.

Regarding nursing student's experience on their learning performance, the current study clarified that, all dimensions of learning performance for the participated students were high more than half percent. When the internal pattern of the activity dimension was observed, it could be understood that the factors that have become prominent were while I am studying, I often stop and do something else, in dimension of perception and understanding; all the factors were prominent and affect learning performance. in dimension of listening; the factor of I like reading aloud, in dimension of abilities; I like doing things by using my hands, in dimension of method; I like my teacher to correct my mistakes by explaining them to me, in dimension of noticing; I understand better if events and subjects are dramatized. These findings may be due to internal locus of control of the participated students in the current study was high and the student with high internal locus of control when studies hard and does well on a test, he attribute his success to his actions and abilities so he become motivated and continue to study hard while the student with high external locus of control, when he does well on a test he believe that the success is due to luck or an a easy test not to his actions or abilities and with the time he don't achieve academically well.

These results were in the same line with [18].

Concerning to nursing student's experience regarding perceived academic support, the present study showed that, high academic support more than two thirds percent as perceived by the participated students. This result may be due to access, availability and shared context of clinical instructors at faculties of nursing. This result was supported by [3] who carried out a study entitled "Student Academic Support as Predictor of Academic Locus of Control in Turkish University Students" and [20] who study Stress and Perceived Faculty Support among Foreign - Born Baccalaureate Nursing Students; they reported that the participated students perceived a high faculty support.

Regarding relationship between locus of control and learning performance, the current study revealed that, there was no significant correlation between internal locus of control and learning performance total score, this result could be interpreted as (MD) of internal locus of control was lower in Suez Canal University than Mansoura University and that above moderate with minimum degree while the learning performance was high in two universities so there was no significant correlation between internal locus of control and learning performance total score. While there was positive significant correlation between internal locus of control and dimension of perception and understanding due to the study sample practice the problem based learning approach so the students were more independent in their learning.

These results was in the same line with [17] who study Academic Self- Efficacy, Locus of Control and Academic Performance of Secondary School Students in Ondo State, Nigeria, they found that locus of control wasn't a good predicator for learning performance. While in contrast with [4] who carried out a study entitled "A Study on Locus of Control and Its Impact on Employee's Performance who reported that internal locus of control was a strong predicator for employee's performance.

The finding of the present study revealed that, there was negative correlation between external locus of control and learning performance total score. Also there was negative correlation between external locus of control and dimension of perception and understanding and dimension of abilities respectively. Similar results were reported by [4], [1] and 
[11] who carried out a study entitled "Is There any Connection between Academic Performance, Locus of Control and Learning Styles?" they reported that external locus of control was a passive predicator for employee's performance.

As regard to relationship between locus of control and perceived academic support, the current study clarified that, there was no significant correlation between locus of control whether internal or external and perceived academic support total score. This result could be interpreted as the difference between mean \pm SD of locus of control and perceived academic support were high. Arslan et al. [3] found that positive correlation between the student academic support and the internal locus of control and negative correlation with external locus of control, he stated that students would be eager to select other students for academic support rather than teacher.

Concerning to comparison between Suez Canal University and Mansoura university regarding locus of control, learning performance and perceived academic support, the result of the current study clarified that, mean $\pm \mathrm{SD}$ of locus of control whether internal or external, learning performance and perceived academic support were high in Mansoura university with minimal degree and this may be due to the number of students who participate in Mansoura university more than ones Suez Canal University. The dimension of perception and understanding in learning performance was the only dimension high in Suez Canal University rather than Mansoura University and that may be due to the small number of students enrolled in each course.

\section{Conclusion}

Students with internal locus of control higher than students with external locus of control and there was no significant correlation between locus of control (internal or external) and learning performance or perceived academic support. There was difference changes between study variables at faculty of nursing, Mansoura University rather than faculty of nursing, Suez Canal University.

\section{Recommendations}

a. Academic administrators should pay attention to help students to understand how their perceptions about self may affect their academic performance.

b. Universities governance and administrators should develop policies regarding coaching mentoring and counseling undergraduates.

c. Colleges and universities orientation sessions should in include presentations and classes on the variables that affect locus of control.

d. Use of different assessment techniques in planning the learning activities.

e. Using new learning strategies which struggled to be produced.

f. Adopt continuous learning philosophy, students should take responsibility of learning, obtaining value and feedback constantly, focusing on flexibility to increase the effectiveness of the organizational learning.

\section{References}

[1] Abid, M. A. and Kanwal, S. (2016): The Effect of Locus of Control on Academic Performance of the Students at Tertiary level. International Review of Management and Business Research. ISSN: 2306-9007, Vol. 5 Issue.3, Pp. 860-869. www.irmbrjournal.com.

[2] Rotter, J.B. (1966): Generalized Expectancies for Internal Versus External Control of Reinforcement Psychological Monographs, 80, 1-28.

[3] Arslan, S. \& Cardak, M. and Uysal, R. (2013): Student Academic Support as A predictor of Academic Locus of Control in Turkish University Students. Procedia-Social and Behavioral Sciences. 106, pp. 2460-2469.

[4] Mali, V. (2013): A Study on Locus of Control and its Impact on Employees' Performance. International Journal of Science and Research (IJSR) ISSN (Online): 2319-7064Volume 2 Issue 12, December 2013. PP 149-151 www.ijsr.net.

[5] Hasan, S. S. and Khalid, R. (2014): Academic Locus of Control of High and Low Achieving Students. Journal of Research and Reflections in Education June 2014, Vol.8, No.1, pp 22 -33 http://www.ue.edu.pk/jrre.

[6] Gulveren, H. (2008): Investigation of Relations between Internal-External Locus of Control Trait Anger, Anger Expression Styles and Intelligence in 12 Grade High School Students. Unpublished Master's Thesis. Maltepe University, Social Sciences Institute, Istanbul.

[7] Kutanis, R. O. (2010): Organizational Culture (Lecture Notes). First Press, Sakarya: Bookshop.

[8] Akin, A. (2010): Achievement Goals and Academic Locus of Control; A Structural Equation Modeling Approach. Eurasian Journal of Educational Research, 1-18.

[9] Erdogan, B. (2003): Effects of Background Information and Locus of Control on Student's Control Preferences in WebBased Instruction. Unpublished Master's Thesis, Ankara University, Education Sciences Institute, Ankara.

[10] Chamorro-Premuzic, T., \& Furnham, A. (2006): Intellectual Competence and The Intelligent Personality: A Third Way in Differential Psychology. Review of General Psychology, 10, 251-267.

[11] Shehu, A. \& Bushi, N. (2015): Is There any Connection between Academic Performance, Locus of Control and Learning Styles? Academic Journal of Interdisciplinary Studies. MCSER Publishing, Rome-Italy. ISSN 2281-3993, Vol 4 No 2 S2, Pp. 188-198.

[12] Keup, J. P. \& Mullins, E. (2010): Findings From National Survey of Peer Leadership Experiences and Outcomes. Concurrent Session Presented at the $29^{\text {th }}$ Annual Conference on the First- Year Experience, Denver, and February.

[13] Maxwell, M. (2001): Peer Tutor in: An Overview; History of Research on Program Effectiveness. Journal of The National Tutoring Association, 1(1), 8-18. 
[14] Mazer, J. P. and Thompson, B. (2011): The Validity of The Student Academic Support Scale: Association with Social Support and Relational Closeness. Communication Reports, 24(2), 74-85. MCSER Publishing, Rome-Italy ISSN 20399340Vol 4 No 11, Pp 570-576.

[15] Rahman, R. M. (2016): The Relationship between Locus of Control and Academic Achievement and Gender in a selected Higher Education Institution in Jordan. Faculty of Education, University Kebangsaan Malaysia, 34(4), 215-220. Retrieved at March 30, 2016.

[16] Gungor, I. (2006): Education High School First Grade Students with Learning to Learn Mathematics Achievement Effects of Turkish Language and Literature Courses Exam (Example of the city of Kayseri). Unpublished Master's Thesis. Erciyes University, Social Sciences Institute, Kayseri.

[17] Ogunmakin, A. O. \& Akomolafe, M. J. (2013): Academic
Self-Efficacy, Locus of Control and Academic Performance of Secondary School Students in Ondo State, Nigeria. Mediterranean Journal of Social Sciences.

[18] Kutanis, R. O., Mesci, M. \& Ovdur, Z. (2011): The Effects of Locus of Control on Learning Performance: A Case of an Academic Organization. Journal of Economic and Social Studies. Vol. 1, No. 2, Pp. 123-133.

[19] Anderson, T. L. (2007): The Impact of Locus of Control Reinforcements and Metacognition on Mathematics Achievement of Undergraduate Students. UMI Microform 3317484 Copyright 2008 by ProQuest LLC. 789 E. Eisenhower Parkway. PO Box 1346. Ann Arbor. Ml 481061346.

[20] Malecha, A. (2010): Stress and Perceived Faculty Support among Foreign-Born Baccalaureate Nursing Students. Journal of Nursing Education • Vol. 49, No. 5, Pp. 261-269. 